\title{
TRANSFORMATION OF RETAILING IN POST-COMMUNIST SLOVAKIA IN THE CONTEXT OF GLOBALIZATION
}

\author{
František Križan, Kristína Bilková, Pavol Kita, Tomáš Siviček
}

\section{Introduction}

Globalization can influence economies in the transformation in a variety of ways (Blanchard, 1997; Charap \& Dyba, 1991; Jarmołowicz \& Piatek, 2013; Kita, 2008; Rumpel et al., 2013; Svejnar, 2002; Urbšienè, 2013) and in addition to this, the geographical point of view in this topic is relevant (Coe, 2004; Wrigley 2000). Some of the authors claim, that geography plays a key role in the success of a business (Roig-Tierno et al., 2013).

The retail business sector is the fastest changing sector for the most post-communist economies. There are several reasons for this but, perhaps, the most important is the legacy of widespread neglect, reglementation and shortages that preceded the peaceful conversion from the centrally planned to a market economy in 1989 (Michalak, 2001). The transformation of the retail business sector has been accelerated by the influence of multinational business corporations (cf. Wrigley et al., 2005).

Slovakian retial sector retail has gone through a lot of changes throughout its development (Fertal'ová, 2005; Fertal'ová \& Szczyrba, 2006; Križan \& Lauko, 2014; Mitríková, 2008; Očovský, 1973, 1974, 1976; Pulpitlová, 2003; Trembošová, 2012). All of these changes can be characterized by the process of transformation. The first group entails the following changes: an alteration of the function of retailing in the sense of its position in the economy (Economic aspect) together with that of an alteration of their relationship towards the customers. Retailing can be considered as more than a mere sector of the economy, it can be a place of implementation of tourism as well (Mitríková et al., 2012; Timothy, 2005). Another form of change is that of the implementation of the way in which retailing is undertaken, which can in turn relate to customer behaviour. (Kunc et al., 2013; Mansvelt, 2005; Maryáš et al., 2014; Spilková, 2012). Changes in retailing are often connected to the concept of globalization, but Globalization does not have to result in the transformation, respectively the manifestation of the globalization process can vary in time and position in the context of the entire transformation processes. Reasons for this can be caused by the influence of political, cultural or economic factors. Political influences result in a form of isolation from the manifestation of globalization even though the retail sector is undergoing a transformation. Good example is the transformation of the retail sector in Slovakia between 1948 and 1989 (cf. Očovský, 1974). In case of cultural influences, the tradition and existing values of the society had a greater influence than that emanating from globalization. Thus globalization has had only a limited effect on the transformation of the retail sector. The last group is the economic influence which is represented by area based by economic activity and by the ability of the retail seller to satisfy his needs even in less developed regions. Private retail sellers always react according to the market situation and are not forced to provide services without a profit as it was in the after war period in Slovakia, where the state retail sector provided basic services even in the outermost and the least developed regions. The transformation of the state retail sector into private retail sector emerged after the transition to the market economy, led to subsequent alterations in the spatial organisation of the retail sector.

The transformation of the retail sector is analyzed in this article in the sense of time and space of the change of the realization of retail selling and in the context of the evaluation of the factors influencing these changes. The main aim of this article is to evaluate the development of retailing in Slovakia in the context of the processes of transformation. The 
transformation of retailing is evaluated in time and space with specific attention paid to the globalization processes and their manifestation in Slovakian retailing.

\section{Methods and Data}

Methods applied in this article can be divided into two groups. The first group of methods is represented by the analysis of relevant literature, which focuses on the development of retail sector prior the 1989 together with a subsequent analysis of official statistical data. It is a descriptive analysis of the retail sector in Slovakia and the ongoing processes in this sector. The analysis also concentrates on time related development in this sector.

The second group of methods focuses on a comparative analysis of some aspects relating to time and space manifestation in the sector (Szczyrba, 2010). It evaluates the impact of globalization processes in Slovak Retail. The main goal is to enable the expansion of the retail sector in Slovakia to be identified (Kotulic \& Marchevská, 2013). Selected spatial data were geo-coded in the interface of Geographical Information Systems and analyzed. The analysis of urban and rural environment was done separately. The results were interpreted by graphic and cartographic means by GIS tools (Kita, 2013; Klapka et al., 2010) with the objective of documentation of spatial aspects of transformation of retail in Slovakia. The analysis of data relating to Geo-marketing can be done by means of various applications and utilities of GIS (Cliquet, 2013). This article applied basic cartographic tools visualized by means of figural characters.

The data come from three main sources. Two of the sources are: the Statistical office of Slovak Republic and Eurostat from where the data on development of retailing in general and about the retail formats, their spatial localization, as well as about the macroeconomic context (GDP, inflation, employment, gross valueadded) were gathered. The second sources of the data were the selected individual Retail companies from where the data on shops (number and localization) were gathered. This data entailed enabled the analysis of the processes in the Slovakian retail sector.

\section{Retailing in Slovakia prior to 1989}

Trends of the development in Slovak retailing were strongly influenced by political as well as economic conditions in the country (cf. Szczyrba, 2006). To characterize the transformation processes of today's retailing, it is necessary to briefly characterize the development of commerce/retailing in the past as the development and the attributes of retailing and socio-economic conditions contributed to the present image of this sector of the economy.

There is a long history of the development of commerce in Slovakia (Očovský, 1974). One of the important influences on retailing was the creation of specialized shopping places with the concentration of business, markets and fairs. Huge changes in the retailing happened after the First World War and the creation of Czechoslovakia. There were 3 main changes: a rapid development of the business activities in this sector, peddler selling and subsequent development of various cooperatives. The position of commerce had always important role in the economy of the country. Formation of the first shopping centres (ASO, TETA, Brouk, Babka) with uniform prices occurred in this time period as well. The creation of this new type of shopping centres led to both the development of the sector but on the other hand also led to a concentration of retailing and to its more uneven spatial layout.

After the Second World War, the characteristic situation in the retail was that the business network was fragmented with the majority of private ownership as well as with uneven spatial layout. An important change occurred after 1948 with the change of the ownership status. Prior to 1948 , the private ownership businesses formed the majority of businesses, but the situation started to change after the nationalization of commerce and the formation of state commerce. Before 1948 the private ownership of the business formed $88 \%$ of all the business, in 1949 it was $25 \%$ and in 1950 , the proportion of private businesses dropped to $9 \%$. After 1960 , private ownership was nonexistent in the retail sector. This process of closing small stores was connected to the socialization of commerce and was stopped in the 1950's (Fig. 1A). It was a characteristic of socialism to increase the number of stores in cooperatives (Jednota). Both the number of stores as well as the average area of the stores developed unevenly in comparison to the volume growth of the sale (Fig. 1B). The network of retail businesses was underdeveloped and it 


\section{Fig. 1:

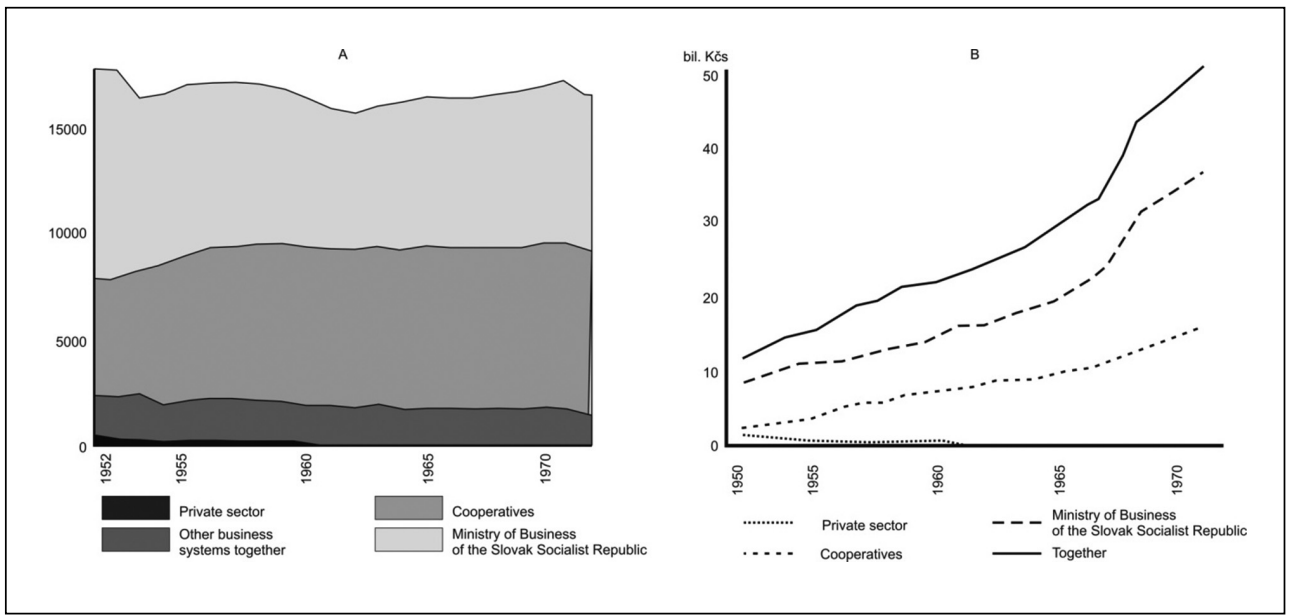

Source: processed according to the statistical yearbooks of the Slovak Republic 1950-1970

did not create sufficient shopping opportunities in comparison to the number and capacity that the retail sector had during this time period.

The main goal of state commerce was to supply mainly cities. Cooperatives were created in the countryside under one common name "Jednota". Another important factor in the development of retail was the implementation of unified prices for all goods, which meant that competition in the retail ceased to exist. The networks of retail businesses started to gradually develop with itinerant sales and the revival of the traditional markets in the country side (Očovský, 1974). The subsequent centralization of the retail sector in the form of shopping centres situated in the centre of the cities was typical for most of the cities. The retail network was formed by 17,000 businesses and from the 1960's onwards, remained unchanged for the next three decades.

In comparison with the developed European economies the retail sector in Slovakia was underdeveloped and in many aspects critically evaluated (Krásný, 1992):

- The density of the retail network (num. of businesses per 1,000 inhabitants) was very low (approx. half of the average in Western Europe). Interesting was to observe the limited scale of the stores in the large cities.

- The capacity of the retail sector (size of the sales area per 1,000 inhabitants) was also very low (approx. one fourth of the size in comparison with the most Western European countries). There was limited ability to supply shops with goods (specifically non-foods).

- Some unfavourable conditions were determined by the value of density and capacity of the retail, this gave rise to conditions to structural deficiency manifested in the limited number of nonfood stores, an absence of modern stores with larger sales area as well as the creation of differences between the local and regional levels in the ability to satisfy customer demands.

\section{Stages of Transformation in the Retail Sector of Slovakia post 1989}

The most important changes in Retail started after 1989 with the shift from the centrallyplanned economy to the free market system. Krásný (1992) denotes the time period of the centrally-planned economy existent until 1989 as a long and stressful way from capitalism to capitalism. The sector of retail went through a significant transformation and in a short time period a few transformation processes were manifested by the influence of globalization under the new socio-economic conditions post 1989 (cf. Kunc et al., 2012a). There were 
more factors that influenced the beginning of the transformation: liberalization of the market, the change in the ownership forms, the decentralization and demonopolization of the retail sector and the liberalization of the prices (Krásný, 1992; Pražská et al., 2000). Liberalization of the prices led to the limiting of consumption and eventually led to the development of retailing. A good example of this is the enormous rise in prices from January 1991, where during the course of one day the prices rose up 32\% (Drtina, 1995). According to Eurostat (2015), even in 2000, the annual average change was $12.2 \%$ and in 2003 still at the level of $8.3 \%$ (based on HICP) The price level then stabilized in 2005.

There were several ways of the change of the ownership forms: the restitution of property back to its previous owners, entry of new investors into the economy and the transfer of property to private individuals. Restitution of property was carried out mainly between 1991 and 1992. The process of restitution was implemented by the law num. 403/1990 Z.z. dealing with the reduction the effects and some property injustice, known also as "Restitution law". Privatization took place in two stages, "Small" and "Large" privatization. Small privatization was introduced by the law num. 427/1990 Z.z. dealing with the transfer of ownership from the state to legal entities and individuals. Small Privatization was implemented during the years from 1991-1992 and was finished in 1993. The main goal of the Small Privatization was to support the creation and development of a competitive environment. The sale of the property was carried out by District privatization committees. Large privatization was introduced by the law num. 92/1991 Z.z. dealing with the conditions for the transfer of property from the state to private individuals. There were many forms of sales of these properties by means of auctions, public tenders, direct sales or the free transfer of the property. The development of retailing was strongly influenced by the so-called Coupon privatization that was carried out in two rounds. The main idea was to buy a coupon booklet with investment points, for which people could buy shares in privatized companies. This means of transformation can be considered (in retail as well) as a non-standard one if we take into consideration the socio-political environment and the execution of the privatization.
The transformation from the centrallyplanned economy to a market economy became a revolution for the economy of the country, which manifested itself also in the retail sector. The transformation in the retail sector had different intensity in time and its manifestation varied in space. By analyzing all of the changes in Slovak retail it is then possible to identify several stages of transformation (cf. Kunc et al., 2013):

(i) Atomization of the retail sector.

(ii) Internationalization/Globalization of the retail sector.

(iii) Consolidation of the retail sector.

Each of these stages has its characteristic attributes and manifestations in urban and rural regions. Mitríková (2008, p. 65) observed that the transformation process includes a variety of interrelated, interconnected and complementary changes.

\subsection{Atomization of the Retail Sector in Slovakia}

The process of Atomization of the retail is typical for post-communist countries in relation to the change of political and economic conditions (Szczyrba, 2010). Retail was developing under different conditions from other countries. The centrally-planned economy and its isolation from other markets had to a certain extent conserved the status of retailing, whereby the globalization processes could not have had any influence. The globalization processes started to manifest themselves the transformation to the free market economy. The process of the atomization of the retailing manifests itself with varying intensity. The same applies for different time periods and the scope of the duration and transition to globalization processes.

Mitríková (2008, p. 65-68) states that the development of the retail network can be regarded as the first stage of the transformation (atomization) related to the change of socioeconomic conditions and the change in the political sphere, which happened in the first half of the 1990's. The consequences of the privatization and restructuralization processes were the formation of a large number of trade license accompanied by the liquidation of a large number of larger businesses and the subsequent creation of new smaller businesses. The atomization of commerce could be spatially and organizationally characterized 
by the fragmentation of the structure of the retail sector with the accompanying signs of decentralization and the de-concentration of the retail network. In this sector, there was a growth in the number of businesses followed by the growth in the number of employees in the sphere of commerce and service. The transformation of the retail network in the stage of atomization was carried out without the presence of foreign retail chains. The development of retail was influenced by local private funds and the processes that were connected with the disintegration of state and collective businesses. This all means that the internationalization process in the retail sector in Slovakia had very little effect on the ongoing globalization processes which manifested themselves in the functional and physical spatial structure of the cities (Bednář, 2005).

The business concept structures in the Slovakian market can be characterized during the stage of atomization as unsatisfactory. The most common business concept in retailing in Slovakia was a small self-serving store, a traditional counter store or a mixed goods store, but in case of a wider range of products, it was a shopping centre, and in the case of specialized products, it was a small specialized store or variety store. The production concept was the prevailing marketing concept and the market only started to react to the demands of wide range business concepts and complementary services. The need to widen the range of the business concepts started to be stronger in connection with the differentiation of the consumers and with the emergence of a qualitative and price categorization (Mitríková, 2008).

Bednár (2005) evaluates the process of atomization and its impact on a city at two levels for the transformation process of retailing in the city of Ostrava. The first level represents the change in the spatial structure of a city. In this context, it is necessary to differentiate between changes in the physical structure on one hand and the functional structure of the city on the other hand. In the case of physical structure, there are discussions about the decay or regeneration of the physical shape of the structures and in the case of the functional structure, the discussion is about the change or conservation of the functional usage of the estates, areas, objects and places for retailing (cf. Spilková \& Šefrna, 2010). The second level represents the changes in the retailing structure of a city, that can be characterized as searching for new locations for retail business, change or conservation of the product range of the selling units, an increase in the number of sales units, increase in the gross lettable area, an increase in the number of non-food stores, the fragmentation of the type of ownership of the retail stores and development of stand selling (cf. Fertal'ová, 2004; Trembošová, 2010).

The atomization of retailing led to an increase in the numbers of stores and subsequently to a decrease of the number of inhabitants per store. The selling area grew rapidly which increased the spatial standard. The servicing standard (the number of inhabitants per one employee in the retailing) decreased. This atomization manifested itself in wholesale as well, where a huge increase in registered subjects was recorded. The number of subjects rose from $450(1990)$ to 19,500 (1993). At the end of the year 1992, more than two thirds of the revenues were earned by businesses with less than 25 employees (Drtina, 1995).

The process of atomization is a state where the small area stores ceased to be the centres of the realization of the selling. This change can be seen as an important process as a result of the initial phase of transformation of retail in all post-communist countries. The process of atomization represents a transition phase in the development of the retail sector from the centrally-planned and isolated economy to dynamic globalization processes in the form of the internationalization of the retail sector.

\subsection{Internationalization/Globalization of the Retail Sector in Slovakia}

Internationalization in retail in Slovakia led to the globalization of retail and vice versa. Dicken (1998) finds it important to differentiate between Internationalization and globalization. The internationalization defines as a simple spread of economic activities crossing the national borders. Globalization on the other hand is defined as a functional integration of internationally spread-out activities and is able to reflect qualitative changes in the organization of economic activities. Therefore the focus of this chapter is on the internationalization of retail in Slovakia, but also on the processes of cooperation, the concentration of retail emerging as a result of the influence of the globalization of the society. 
One of the main characteristics of the retail market in Central Eastern Europe is the dominant position of international retail companies (Dries et al., 2007). It is possible to identify several phases of internationalization in Slovakia. There was almost no influence of international retail companies up until the first half of the 1990's. A more intensive market entry on the part of the international companies happened in the second half of the 1990's (Akehurst \& Alexander, 1995; Coe, 2004).

The evaluation of the internationalization of retail in Slovakia can be based on the indicator - the entry of international companies into the Slovakian market. It is almost impossible to evaluate the influence of this entry of all of the international retail companies into Slovakia; therefore, emphasis is placed on the companies that were evaluated (by TERNO, GfK) as the most influential companies in Slovakia according to various criteria from a specific year. The beginning of internationalization is linked to the entry of international companies in some of the Slovak cities (Bratislava, Nitra, etc.), which happened in the first half of the 1990's (cf. Dawson, 1994). A characteristic feature of this phase is the search for the position on the market (Simová, 2010). A lot of companies were not able to succeed in changing the economy of Slovakia, as an example can be Kmart Company that bought a large portion of the Prior shopping network, but in 1996 the company sold all of its acquisitions to the British company TESCO. The second phase of the internationalization can be considered to be the most intensive, when a lot of international companies from Western Europe entered the Slovak market. The entry of international companies was influenced mainly by (Starzyczná, 2010): the atomization of retail, (ii) a deficit in retailing structures, (iii) the weakened position of cooperatives, (iv) insufficient capital resources of domestic firms, (v) attractiveness of the market, (vi) the knowhow advantage of international companies.

Retail in Slovakia was not influenced only by international companies but also by the Slovakian retail sector that reacted to the globalization of the economy. Slovakian small and average sized companies had two possibilities to cope with the reality of internationalization/globalization (Lesáková, 2004). The first possibility was the active engagement of small and average sized companies in the globalization processes in the sense of its transition to the international level. The second possibility is to adapt to the globalization processes and the focusing of the companies only on local or regional market where they apply various types of cooperation. Cooperation among retail sellers occurred even in the post-war period during the start of the central planned economy (Očovský, 1974). The character of the cooperation was very different from the cooperation under the influence of the market economy and globalization. In the past, cooperation in the Slovakian retail sector was implemented only in the form of cooperatives named "spotrebné družstvo". Today there are many forms of cooperation between the businesses: franchising, cluster, union or association (Križan \& Lauko, 2014).

International companies created strong competition pressure on the local retailers. If the local retailers want to make their position on the market firm and if they want to get the best from the relation with the producer and supplier, creation of alliances is necessary, especially for the Slovak companies to be able to compete against international companies. International companies consolidated their position on the Slovakian market. They can keep the prices very low as the amount of their revenue is high and the character of the Slovak consumer enables it. Cooperatives often make joint advertising activities or they coordinate legislative activities, they have the same visual appearance of the stores and they often offer their own brand of products.

Internationalization is a process characteristic for urban areas, cooperations on the other hand are typical also for rural areas. Cooperations created in the rural and peripheral areas are the only chance for the sellers to preserve their position on the market (Szczyrba, 2005; Szczyrba et al., 2012). In the effort to create adequate competition for the global companies, these kinds of cooperation are necessary.

The geographical location of cooperation (specifically franchising) in retailing in Slovakia has different features from those in Western countries, for which there are two typical characteristics. The headquarters of the cooperatives are localized in the cities or in densely populated regions, the cooperation units are situated in sparsely populated regions in the rural areas (Caves \& Murphy, 1976). This kind of spatial structure is not typical 
for Slovakia (Križan \& Lauko, 2014). One of the specific differences is that in the Western Slovakia, the cooperation is concentrated only in the rural areas because of the strong influence of international corporations in the cities, which is in line with the general trend of a time lag from the spreading of the globalization processes from west to east. In eastern Slovakia (partly in Slovakia as well) cooperations in the food retail sector were created in cities as well. Another characteristic is that in rural areas the cooperation is concentrated on food retail only, in the cities the character of the products is more diverse (pharmaceutical, drugstore, electronic retail, etc.). As an example the network of food stores "Môj obchod" were in 2013 localized mainly in the rural areas $(92.6 \%)$, on the other hand a network of stores for electronics and home appliances Euronics is located mainly in the cities as 46 of their 47 stores are located in the cities (Fig. 2).

Cooperatives of retailers in Slovakia can be classified according to the number of stores and its spatial layout into three groups: regional, supra-regional and national. As an example of regional cooperation is the chain of food stores Koruna situated only in the regions of: Kysuce, Orava, Liptov, Horné Považie, Stredné Považie, Turiec, Horná Nitra a Horehronie. The spatial concentration is in one or two self-governing regions (Fig. 3).
Selling networks classified as supraregional cooperations have their stores spatially more dispersed. The stores are located in more self-governing regions, with a possible higher concentration in one of the regions. An example of supra-regional cooperation is the Kinekus Company, with its franchising in the field of household accessories. The network of stores is situated in the region from Bratislava to Ružomberok and therefore is situated only in Western Slovakia. Another example of supraregional cooperation can be Norbi Update and its network of 24 stores mainly situated in Western Slovakia, with fewer stores in Central and with only 2 stores in Eastern Slovakia (Fig. 3).

The transition between the three spatial categories of cooperation is steady, without marked borders. Criteria for each of the categories cannot be rigidly defined. Some companies have more or less the supra-regional character, but some of their stores are situated in regions far away from their supra-regional influence. From the point of the concentration of stores they could be classified as national, but from the point of view of concentration of the stores as supra-national. The cooperation at the highest hierarchical level spatially covers evenly the whole of Slovakia. Cooperation in consideration of the dimension and efficiency

\section{Fig. 2: Example of cooperation in retailing in the cities and rural areas in Slovakia}

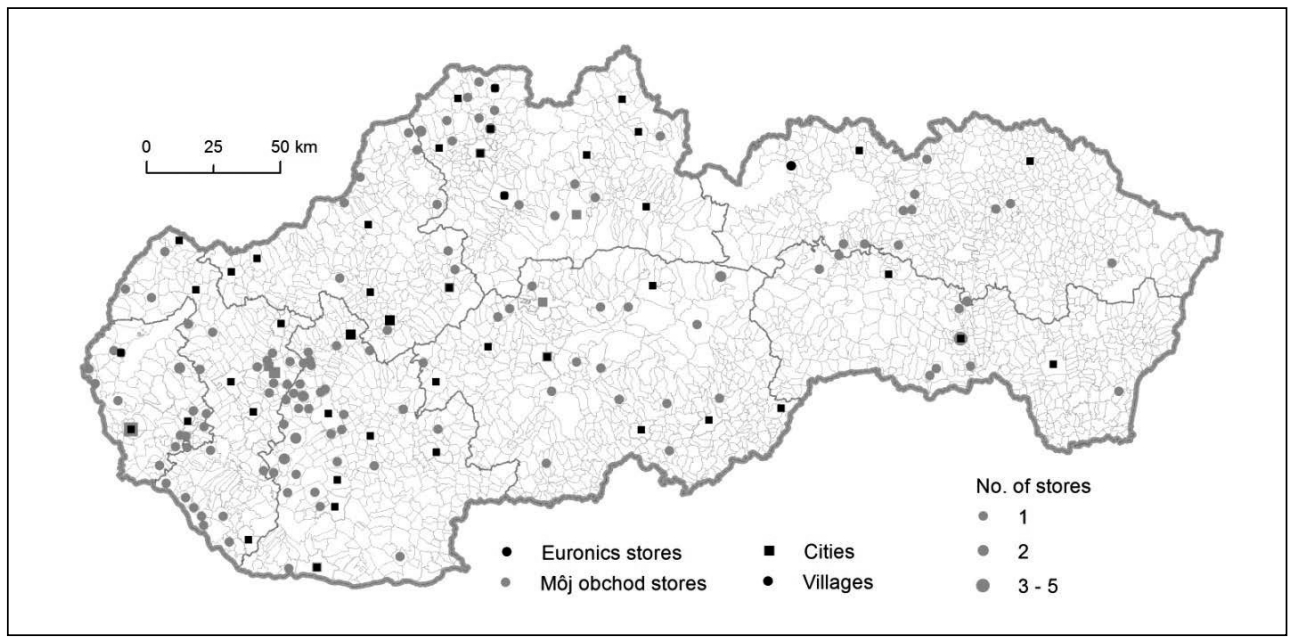

Source: Private databases of the companies (2014) 


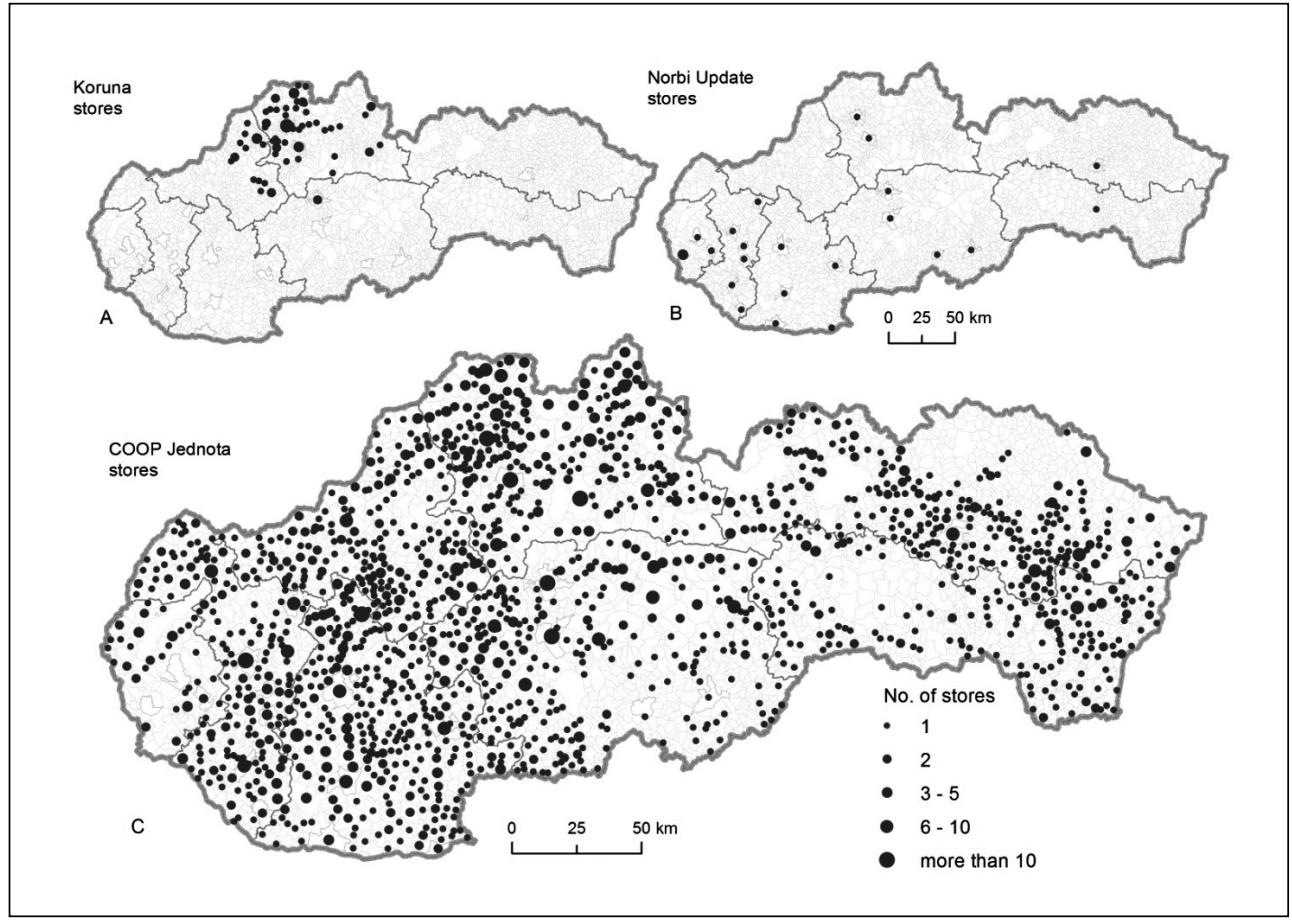

Source: Private databases of the companies (2014)

of operation is often internally divided into smaller units. The most typical companies in the category of national cooperation is the company COOP Jednota with 31 cooperatives and more than 2,200 stores of different sizes (Fig. 3) and the alliance NOBA which unites more than 500 retail sellers or the Bala chain store that has more than 700 stores.

Concentration of the sector is the main feature of this phase of transformation of the retailing sector (cf. Akehurst, 1983; Dobson et al., 2003). The concentration of retailing can be evaluated from two possible aspects (economical and geographical). Economical concentration refers to the increase of the impact of the most influential companies on retail in specific regions. The most intense economical concentration started to take place after the second half of the 1990's. By the analysis of the ranking of the TOP 50 companies in Slovakia, the year 1996 can be considered to be the peak of the de-concentration process (TERNO
Slovakia). The rating of TOP 10 companies was dominated by Slovak retailers until the year 2000. The most significant changes occurred in 2005, when from the TOP 10 companies seven were international. It is important to remark that even though the total revenue of the consumer cooperatives of COOP Jednota were 30 billion Slovak crowns, none of its members was able to achieve ranking in the TOP 10 . This trend continues to the present day (databases of companies TERNO a GfK Slovakia, INCOMA Slovakia).

Geographical concentration refers to the fact that the position of the retailing network is not random, and it is bound to rules, principles with the aim of satisfying the needs of the merchants and customers (Cimler, 1997; Szczyrba, 2005; Konštiak, 2013). One of the principles is the concentration and relative uniformity of spatial distribution of the retailing network. Uniformity of spatial distribution of retailing is understood as the equilibrium 
between supply and demand or as the potential purchasing power of the consumers and the sales capacities of the merchants. In the long-term development of retailing networks, few tendencies can be identified (Szczyrba, 2005): (i) spatial concentration, (ii) service concentration, (iii) product range concentration. Spatial concentration refers to the increased capacity of the retailing networks in localities of concentrated demand and increased frequency of inhabitants (cf. Križan \& Tolmáči, 2012). Concentration of service in retailing is manifested by the increase of the average size of sale units or sales area (Fig. 4). Service concentration refers to the increased abundance of largeformat stores. Product range concentration and specialization refers to the offer of all product lines of large-format units and the occurrence of shopping centres (Križan \& Lauko, 2014).

It is possible to identify four stages of development when evaluating the process of concentration of retailing in Slovakia (cf. Bednář, 2005; Szczyrba, 2005; Szczyrba et al., 2007; Kunc et al., 2013): (i) Stage of the dynamic development in the networks of supermarkets (from 1996);

(ii) Stage of the dynamic development in the networks of hypermarkets (from 1999);

(iii) Stage of the dynamic development in the networks of shopping centres (from 2000);

(iv) Stage of dynamic development in the network of discount stores (from 2004).

The stage of the dynamic development of supermarkets started from 1996 by the entry of Tesco Stores SR to Slovakia after buying shopping houses form the Kmart Company. The progress in time is typical for all of the stages. The number of stores of each of the mentioned sale format is increasing each year. In the year 2012 there were 601 supermarkets mainly in the cities in Slovakia (Fig. 5). This development points to the trend of a percentage increase of supermarkets in the rural villages. The Percentage of supermarkets in the rural area grew from $11.9 \%$ (2001) to $28.1 \%$ (2012) and the building of new supermarkets has also shifted to the cities with a lower number of inhabitants.

\section{Fig. 4: Development of the size of sales area [t. $\left.\mathrm{m}^{2}\right]$ in different retailing formats in Slovakia (1993-2011)}

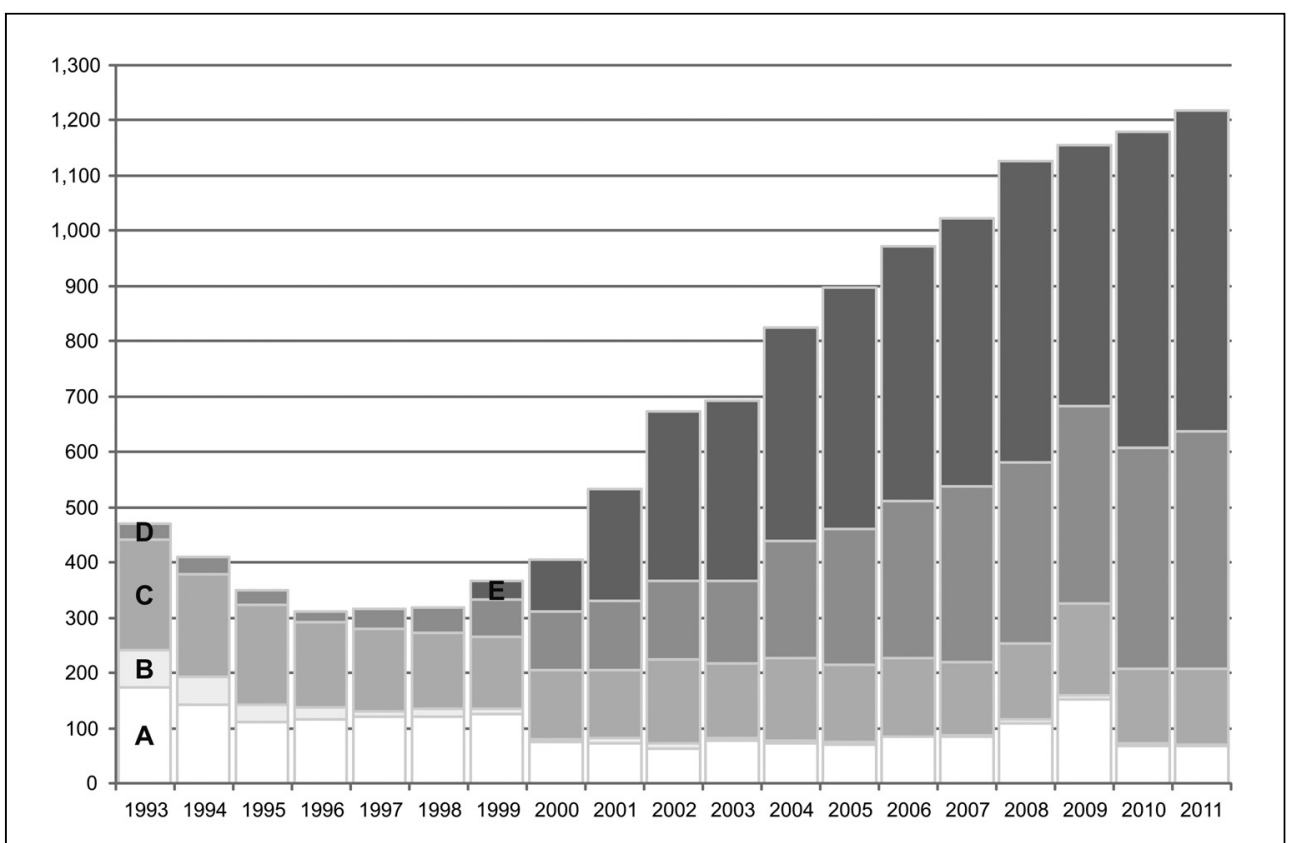

Explanation: A - Shopping houses, B - Shopping centres, C - Variety shops, D - Supermarkets, E - Hypermarkets.

Source: processed according to the statistical yearbooks of the Slovak Republic 1994-2013 
This dynamic rise of the Hypermarkets started from the opening of the first one in Nitra in 1999. Two years later there were 22 hypermarkets and the number increased with an annual rise of $10 \%$ to 154 hypermarkets in 2012 (Fig. 5). The intensity of the rise of hypermarket format is given by the popularity of hypermarkets as the main shopping places as quarter of all sales are made here (GfK Slovakia). There is still an ongoing trend of movement of this type of format to suburban areas of larger cities, like Dunajská Lužná or Ivanka pri Dunaji in the surrounding areas of the capital city. Hypermarkets in the rural areas represent $8.4 \%$ of all hypermarkets. Another important factor for the rise of this type of format in the rural areas is the building of shopping areas, where hypermarkets have their place within the process of commercial suburbanization. (cf. Šveda \& Križan, 2012).

In comparison with the Czech Republic there is some time delay in the rise of the shopping centres in Slovakia (Kunc et al., 2013). The first opened shopping centre in Slovakia was Polus City Centre in Bratislava in 2000. The dynamics of the rise until 2005 was relatively slow as by then only ten new shopping centres were opened from the total of 47 shopping centres of today. The culmination of the building of shopping centres in Slovakia was in 2010 followed by a drastic drop after this year due to the influence of the Economic crisis in this sector of economy. New projects for shopping centres were halted or modified by the developers in the sense of reduction of the dimension of the projects. Some unfinished projects are in search of new investors or they have changed ownership. Many of the projects are in the construction phase (D1 Outlet) or are in the environmental impact assessment (EIA) phase (Pharos Park).

Shopping centres in Slovakia are concentrated predominantly in commercial centres and to the localities with a high concentration of inhabitants, which are usually county cites (Fig. 6). Bratislava has a special position as it has the highest concentration of shopping centres that makes up more than a quarter of all shopping centres in Slovakia (Kunc et al., 2013). The lowest concentration of shopping centres is in County of Banská Bystrica as well as in the counties of Prešov and Trenčín. One of the trends is also the construction of smaller shopping centres with a gross lettable area below $5,000 \mathrm{~m}^{2}$ with localization in smaller regional cities. Examples of projects are: Point (Brezno), Dituria (Levice), Váh (Hlohovec), Ardis (Fil'akovo), project Kocka of the M-Market company etc. The most frequent group of shopping centres is with a gross lettable area between 10,000 to $20,000 \mathrm{~m}^{2}$. Together with the group of shopping centres with gross lettable area less than $10,000 \mathrm{~m}^{2}$ they form more than half $(56.8 \%)$ of all the shopping centres in Slovakia. The group of large shopping centres is the least frequent (cf. Križan \& Lauko, 2014).

When assessing the localization of shopping centres on the border of the city, there were three localizations identified (Guy, 1998): the centre of the city (edge-of-centre), the inner city (out-of-centre) and the suburbs (out-of-town). The most frequent is the localization of shopping centres is in the inner city (56.8\%). Centres in this location also make up the majority share of all of rentable area in shopping centres $(53.5 \%)$, but the average rentable area is the lowest $\left(19,714 \mathrm{~m}^{2}\right)$. The second most frequent localization is in the suburbs $(29.5 \%)$ with a third of all rentable area. These shopping centres have the highest average rentable area $\left(23,492 \mathrm{~m}^{2}\right)$. The least frequent are the shopping centres situated in the city centres $(13.6 \%)$, with the smallest share of all rentable area $(13.4 \%)$ and with average rentable area $\left(20,617 \mathrm{~m}^{2}\right)$. All shopping centres built in the city centres belong to the group of Brownfield shopping centres, in the case of the inner city it is $84 \%$. In the suburb areas the most dominant are Greenfield shopping centres (77\%). Greenfield shopping centres form overall the majority of the shopping centres $(54.5 \%)$.

The stage of the dynamic rise of network of discount stores began with the expansion of the retail chain LIDL in 2004, even though there was a discount chain Nitrazdroj even before this date. Lidl built up a strong position on the Slovakian market and from 2005 the chain is represented in the TOP 10 wide range merchants in Slovakia. In comparison with the Czech Republic, there is a significant time lag in this phase of transformation of Retailing (Kunc et al., 2013). The phase of the dynamic rise of discount chains is under the long-term influence of a few companies (Lidl, Nitrazdroj, CBA). The Slovakian market was less appealing for other discount chains. A change occurred in 2013, 
o $2550 \mathrm{~km}$
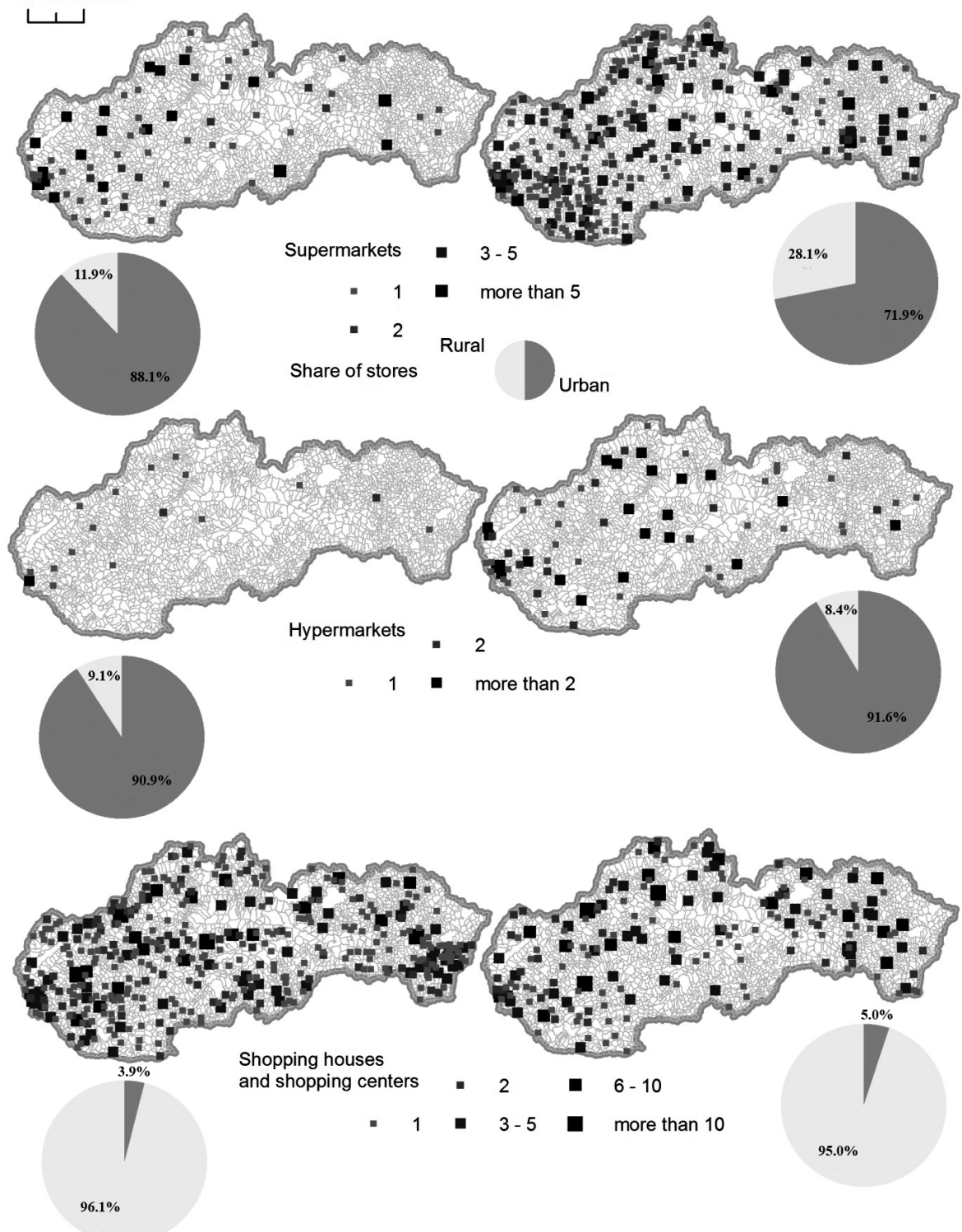

Source: own based on Statistical office of Slovak Republic (2014) 


\section{Fig. 6: Shopping centres in Slovakia in 2012}

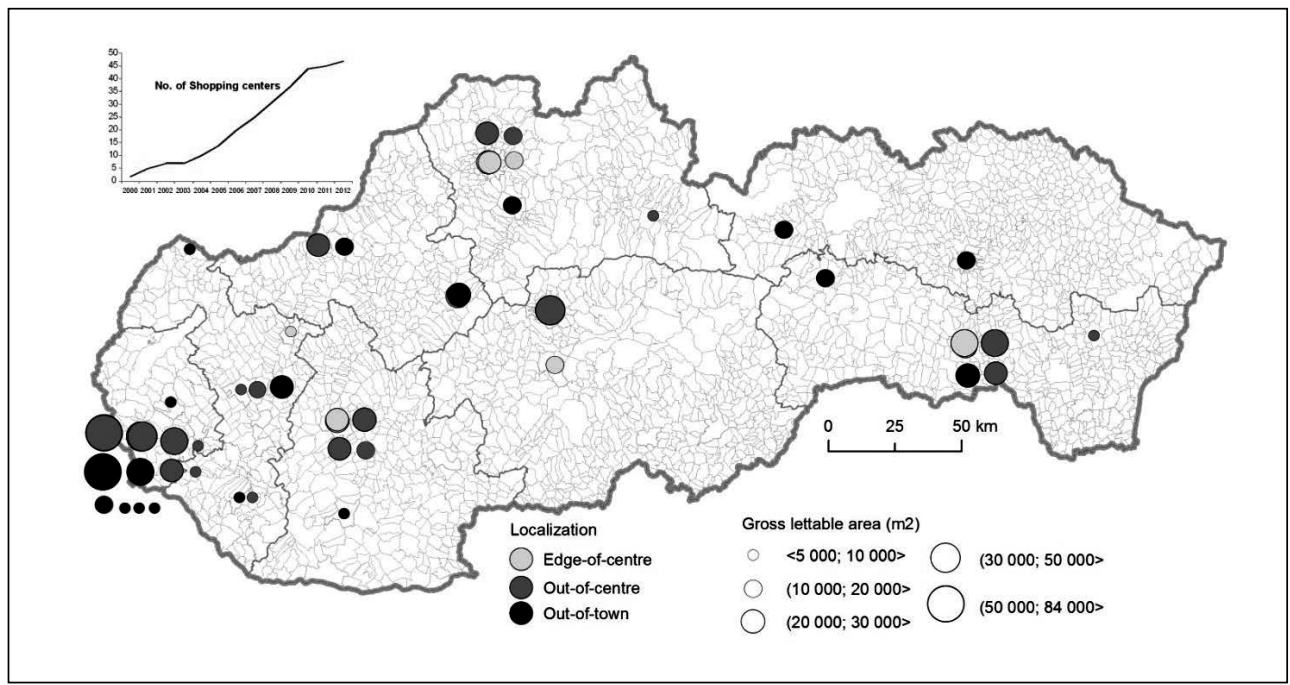

Source: own based on Kunc et al. (2013)

when a new non-food discount chain Pepco came to Slovakia.

Shopping houses in Slovakia are defined as a retail unit that is formed by a variety of sales departments with joined operation within one building. Shopping house offers a wide variety of product ranges (food, clothing and manufacturing products), usually also public cafeterias and other additional services. The minimal sales area is $1,500 \mathrm{~m}^{2}$, but in the villages exceptionally only $1,000 \mathrm{~m}^{2}$. The shopping centre is defined as a retail unit with a wide variety of product ranges supplying at least three basic product range groups (food, clothing and manufacturing products) within at least two separate sales departments within one building. The departments have the same operator. A shopping centre has the sales area between $250 \mathrm{~m}^{2}$ and $1,000 \mathrm{~m}^{2}$ (in the rural area), outside the rural area up to $1,500 \mathrm{~m}^{2}$ (Statistical office of Slovak Republic, 2014). At the shopping centres there were the most important concentrations of retail activities before the transformation. The number of shopping houses and shopping centres culminated in 2001 with the number 771 . This number is more than 200 higher than in 1996 but 300 less than in 2012. These types of retail formats were designated mainly for the rural areas (96.1\% stores in 2001), where they supplied not only the villages in which they were situated, but also surrounding villages. The introduction of new forms of sale (the stage of the rise of supermarkets, hypermarkets or discount stores) resulted in the outflow of the customers to the localities of the concentration of the new sales formats, which resulted in 2012 in a more significant decrease in the number of stores in the rural area (95\% stores) in comparison with the cities (Fig. 5).

\subsection{The Consolidation of Retailing in Slovakia}

After the rapid growth in the retail that continued till the end of the millennia, the intensity of the revenue increased and the growth of the number of international corporations that entered the market slowed down. The market reached the phase of consolidation. M. Trembošová (2012) does not consider the phase of the transformation to be completed. The next phase of this stage of the development of retailing is the departure of international corporations from the market. The consolidation phase in Czech Republic began in 2006 (Kunc et al., 2013). In the case of Slovakia, there is a time lag in the onset of this phase and has begun to become reality only in recent years. 
The consolidation has a differing history in the various sectors of retailing and it can be observed simultaneously with the process of internationalization. The consolidation of sport equipment retailing is the most recent case of this phase. The increase in competition and the pressure on the gains of the companies has forced some companies to leave the market: Alpha Pro Sport, Športpro, RM Športline or Gigasport. On the other hand, the departure of these companies has become the foundation for the expansion of other companies (SportsDirect.com, Decathlon).

The consolidation also manifests itself by means of the merger or sale of companies to other retailers on the market. There are a few examples in the Slovakian market: the acquisition of the Carrefour Slovakia by the Tesco Stores Slovakia, departure of Ahold Retail Slovakia from the market, acquisitions of 20 Hypernova stores and 4 Albert stores by the Condorum company that owns the chains of TERNO and the Moja Samoška, acquisition of Electro World stores by NAY in both the Czech and Slovakian market.

Another manifestation of the consolidation and transformation of retailing in Slovakia can be connected with the change in consumer behaviour and a partial diversion from shopping in shopping centres. Some authors termed this stage as diversification of retailing (Mulíček \& Osman, 2013). In the concentration of retail structures, there is a slowing down associated with new localization strategies retailers (Kunc et al., 2012b). There are new preferences among the customers: Farm markets and alternative food networks (Spilková \& Perlín, 2013). Farm markets are a new trend specifically in the cities (Spilková et al., 2013). The models of consumption change towards more ethical and health characteristics of the consumption which results in a new dimension for the transformation of retailing in Slovakia.

Retail together with Wholesale (G-I NACE ver.2) belong to sectors contributing significantly to employment in the Slovakian economy. In years 2009-2011, the share on all NACE (ver.2) activities was stable at $27 \%$ after the growth trend, apparent over previous years. However, its share of the gross valueadded has oscillated by around $22 \%$ during the last decade. The Bratislava region (NUTS III) as the most advanced region in Slovakia registered a stable share above $30 \%$ during the same period (Eurostat, 2015). Although the dynamics of retail trade volume in pre-crisis period was higher than the real GDP annual growth rate, since due to its vulnerability, it has suffered more and its recovery has been slower (Eurostat, 2015).

\section{Conclusion}

The development of retailing in Slovakia has been unified by globalization processes. On the other hand the development of retailing in Slovakia is individual by globalization processes in the context of intensity and timing of some selected transformation processes. The transformation of retailing in Slovakia was during the communism strongly influenced by the political elites of the centrally-planned economy, which in turn was manifested by insufficient development, capacity and diversity and other characteristics in comparison to the developed countries. After the transformation to the market economy, the further transformation processes in the retailing sector in Slovakia started to lag in comparison with the developed countries.

By evaluating the transformation processes in retailing in Slovakia it is possible to reach a few general conclusions.

Ad 1. All of the globalization processes identified in the developed countries that transformed the retailing sector in cities and countryside manifested themselves in Slovakia as well. The manifestations of globalizational processes in retailing are stronger in the cities (cf. Križan \& Lauko 2014).

Ad 2. The time lag of the transformational processes in Slovakia in comparison with the surrounding countries is typical. Studies in the Czech Republic show that the time lag in the transformation processes occurred from the west to the east of the country (cf. Kunc et al., 2013).

Ad 3. The dimension of the market influences an intensity of the globalization processes. Processes in the cities are more apparent (cf. Bilková \& Križan, 2013).

Ad 4. Consolidation of retailing in Slovakia can be evaluated as being the transformation in the initial phase. Dominant manifestations are: the internationalization and that of the life cycle of retailing not achieved in the mature phase (cf. Szczyrba, 2005). 
This work was supported by the VEGA project named Regions: development, transformation and regional differentiation (contracts No. 1/1143/12), the VEGA project named Specifics of time-space human behaviour under the impact of socio-economic changes (No. 1/0082/15).

\section{References}

Akehurst, G. (1983). Concentration in retail distribution: measurement and significance. Service Industries Journal, 3(2), 161-179. doi:10.1080/02642068300000022.

Akehurst, G., \& Alexander, A. (1995). Developing a framework for the study of the internationalisation of retailing. The Service Industries Journal, 15(4), 204-209. doi:10.1080/02642069500000058.

Bednář, P. (2005). Geografie maloobchodní sítě $v$ polycentrickém městě. Acta Facultatis Rerum Naturalium Universitatis Comenianae, Geographica (Supplementum), 3, 30-42.

Bilková, K., \& Križan, F. (2013). Koncentrácia podnikatel'ských subjektov $\mathrm{v}$ maloobchode v slovenských mestách. Geographia Cassoviensis, 7(1), 31-44.

Blanchard, O. (1997). The economics of post-communist transition. Oxford: Clarendon press.

Caves, R., Murphy, W. 1976. Franchising: Firms, markets, and intangible assets. Southern Economic Journal, 42(4), 572-586. doi:10.2307/1056250.

Charap, J., \& Dyba, K. (1991). Transition to a market economy: The case of Czechoslovakia. European Economic Review, 35(2), 581-590. doi:10.1016/0014-2921(91)90160-K.

Cimler, P. (1997). Retail management: lokalizace a provoz maloobchod. Praha: Vysoká škola ekonomická.

Cliquet, G. (Ed.). (2013). Geomarketing: Methods and strategies in spatial marketing. London: John Wiley \& Sons.

Coe, N. (2004). The internationalisation/ globalisation of retailing: towards an economicgeographical research agenda. Environment and Planning A, 36(9), 1571-1594. doi:10.1068/ a36241.

Dawson, J. (1994). Internationalization of retailing operations. Journal of Marketing Management, 10(4), 267-282. doi:10.1080/026 7257X.1994.9964274.

Dicken, P. (1998). Global Shift. London: Paul Chapman.
Dobson, P.W., Waterson, M., \& Davies, S.W. (2003). The patterns and implications of increasing concentration in European food retailing. Journal of Agricultural Economics, 54(1), 111-125. doi:10.1111/j.1477-9552.2003.tb00053.x.

Dries, L., Reardon, T., \& Van Kerckhove, E. (2007). The Impact of Retail Investments in the Czech Republic, Slovakia, Poland and the Russian Federation. In J. Swinnen (Ed.), Global Supply Chains, Standards and the Poor (pp. 228-240). Oxon: Cabi.

Drtina, T. (1995). The Internationalisation of Retailing in the Czechand Slovak Republics. The Service Industries Journal, 15(4), 191-203. doi:10.1080/02642069500000057.

EUROSTAT. (2015). Database. Retrieved March 24, 2015, from http://ec.europa.eu/ eurostat/data/database.

Fertal'ová, J. (2004). Regionálnogeografické aspekty hodnotenia vývoja maloobchodu na Slovensku po roku 1989. Folia Geographica, 42(8), 5-12.

Fertal'ová, J. (2005). Regionálnogeografické aspekty hodnotenia vývoja maloobchodu na Slovensku po roku 1989. Folia Geographica, 8, 5-12.

Fertal'ová, J., \& Szczyrba, Z. (2006). Globalisation in Czech and Slovak retail: common and specific features. In V. Baar (Ed.), Globalisation and its impact to society, regions and states (pp. 164-172). Ostrava: University of Ostrava.

GfK Slovakia. (2014). Data for retail. Retrieved March 11, 2014, from http://www.gfk. com/sk.

Guy, C. (1998). Classifications of retail stores and shopping centres: some methodological issues. GeoJournal, 45(4), 255-264. doi:10.1023/A:1006960414161.

Incoma Slovakia. (2014). Data for retail. Retrieved March 15, 2014, from http://www. incoma.sk.

Jarmołowicz, W., \& Piatek, D. (2013). Economy of Poland, the Czech Republic and Hungary after 20 years of transition. Transformation in Business \& Economics, 12(2B), 293-304.

Kita, J. (2013). Geomerketing - teoretické a praktické aspekty novej vízie marketingového prístupu. Bratislava: Ekonóm.

Kita, P. (2008). K niektorým aspektom koncentrácie a konkurencie $v$ oblasti distribúcie v kontexte globalizácie. Ekonomický časopis, 56(9), 912-924. 
Klapka, P., Frantál, B., Halás, M., \& Kunc, J. (2010). Spatial organisation: development, structure and approximation of geographical systems. Moravian Geographical Reports, 18(3), 53-65.

Konštiak, P. (2014). Geomarketing-nástroj zmeny fungovania maloobchodných jednotiek. Studia commercialia Bratislavensia. 7(26), 226-236.

Kotulic, R., \& Marchevská, M. (2013). Concentration of the retail network in relation to the consumer shopping behavior in regions of the Slovak Republic. Polish Journal of Management Studies, 8(1), 141-156.

Krásný, T. (1992). Retailing in Czechoslovakia. International Journal of Retail and Distribution Management, 20(6), 30-33. doi:10.1108/EUM0000000002966.

Križan, F., \& Lauko, V. (2014). Geografia maloobchodu. Úvod do problematiky. Bratislava: Univerzita Komenského.

Križan, F., \& Tolmáči, L. (2012). Geografické informačné systémy ako nástroje vizualizácie $v$ problematike maloobchod: úvod do problematiky. In P. Kita (Ed.), Možnosti využitia geografickéhoinformačného systému ako zdroja strategickej inovácie podniku z hladiska posilnenia jeho konkurencieschopnosti podnikov (pp. 57-65). Bratislava: Vydavatel'stvo Ekonóm.

Kunc, J., Tonev, P., Szczyrba, Z., \& Frantál, B. (2012a). Commuting for Retail Shopping as a Part of the Daily Urban System (Brno, the Czech Republic). Geographia Technica, 13(1), 36-45.

Kunc, J., Frantál, B., Tonev, P., \& Szczyrba, Z. (2012b): Spatial Patterns of Daily and Nondaily Commuting for Retail Shopping: Case of the Brno City, Czech Republic. Moravian Geographical Reports, 20(4), 39-54.

Kunc, J., et al. (2013). Časoprostorové modely nákupního chování české populace. Brno: Masarykova univerzita. doi:10.5817/ CZ.MUNI.M210-6020-2013.

Lesáková, L'. (2004). Malé a stredné podniky $\mathrm{v}$ procese globalizácie. Ekonomický časopis, 82(9), 1148-1161.

Mansvelt, J. (2005). Geographies of Consumption. London: Sage.

Maryáš, J., Kunc, J., Tonev, P., \& Szczyrba, Z. (2014). Shopping and Services Related Travel in the Hinterland of Brno: Changes from the Socialist Period to the Present. Moravian Geographical Reports, 22(3), 18-28.
Michalak, W. (2001). Retail in Poland: An assessment of changing market and foreign investment conditions. Canadian Journal of Regional Science, 24(3), 485-504.

Mitríková, J. (2008). Geografické aspekty transformácie maloobchodu a nákupného správania sa na Slovensku (prípadové štúdie z miest Prešov a Košice). Prešov: Prešovska univerzita $v$ Prešove.

Mitríková, J., Tomčíková, I., \& Lukáčová, A. (2012). Trávenie vol'ného času obyvatel'mi Košíc $v$ nákupných centrách ako nový druh víkendového cestovného ruchu. Význam ludského potenciálu $v$ regionálnom rozvoji. In J. Vitovská (Ed.), Význam l'udského potenciálu $\checkmark$ regionálnom rozvoji (pp. 69-90). Podhájska: EEDA.

Mulíček, O., \& Osman, R. (2013). Průzkumu maloobchodní sítě na území města Brna 2013. Brno: Geografický ústav, Masarykova univerzita.

Očovský, Š. (1973). Geografická problematika obchodu na juhozápadnom Slovensku. Geografický časopis, 25(2), 289-298.

Očovský, Š. (1974). Priestorové črty tovarovej výmeny. In P. Plesník, et al. (Eds.), Slovensko - L'ud (pp. 211-242). Bratislava: Obzor.

Očovský, Š. (1976). Vybrané problémy štúdia nákupných miest. Geografický časopis, 28(1), 23-36.

Pražská, L., et al. (2000). Globalizace a obchod. Praha: Vysoká škola ekonomická.

Pulpitlová, M. (2003). Transformácia maloobchodnej siete $\mathrm{v}$ SR. In S. Novák (Ed.), Geografie IV: Geografické aspekty středoevropského prostoru (pp. 133-137). Brno: Masarykova univerzita.

Roig-Tierno, N., Baviera-Puig, A., BuitragoVera, J., \& Mas-Verdu, F. (2013). The retail site location decision process using GIS and the analytical hierarchy process. Applied Geography, 40(June), 191-198. doi:10.1016/j. apgeog.2013.03.005.

Rumpel, P., Slach, O., \& Koutský, J. (2013). Shrinking cities and governance of economic regeneration: The case of Ostrava. E\&M Ekonomie a Management, 16(2), 113-128.

Simová, J. (2010). Internationalization in the process of the Czech retail development. E\&M Ekonomie a Management, 13(2), 78-91.

Spilková, J. (2012). Geografie maloobchodu a spotřeby: věda o nakupování. Praha: Karolinum. 
Spilková, J., Fendrychová, L., \& Syrovátková, M. (2013). Farmers' markets in Prague: a new challenge within the urban shoppingscape. Agriculture and Human Values, 30(2), 179-191. doi:10.1007/s10460-012-9395-5.

Spilková, J., \& Perlín, R. (2013). Farmers' markets in Czechia: Risks and possibilities. Journal of Rural Studies, 32(October), 220-229. doi:10.1016/j.jurstud.2013.07.001.

Spilková, J., \& Šefrna, L. (2010). Uncoordinated new retail development and its impact on land use and soils: A pilot study on the urban fringe of Prague, Czech Republic. Landscape and Urban Planning, 94(2), 141148. doi:10.1016/j.landurbplan.2009.09.001.

Statistical office of Slovak Republic (19502013). Statistical yearbooks of the Slovak Republic 1950-2013. Bratislava: Statistical office of Slovak Republic.

Statistical office of Slovak Republic (2014). Data for retail. Retrieved September 24, 2014, from www.statistics.sk.

Starzyczná, H. (2010). Vybrané aspekty internacionalizace vnitřního obchodu v teoretických přístupech a empirickém zkoumání $v$ České republice $v$ období transformace. E\&M Ekonomie a Management, 6(1), 115-130.

Šveda, M., \& Križan, F. (2012). Prejavy komerčnej suburbanizácie vo vybraných odvetviach hospodárstva v zázemí Bratislavy. Ekonomický časopis, 60(5), 460-481.

Svejnar, J. (2002). Transition economies: Performance and challenges. Journal of Economic Perspectives, 16(1), 3-28.

Szczyrba, Z. (2005). Maloobchod v České republice po roce 1989: vývoj a trendy se zaměřením na geografickou organizaci. Olomouc: Univerzita Palackého.

Szczyrba, Z. (2006). Geografie obchodu - se zaměřením na současné trendy $v$ maloobchodě. Olomouc: Univerzita Palackého v Olomouci.

Szczyrba, Z. (2010). Development of retail geographical structure in the Czech Republic: a contribution to the study of urban environment changes. Acta Universitatis Palackianae Olomucensis, Geographica, 41(2), 5-20.

Szczyrba, Z., Fiedor, D., \& Kunc, J. (2013). Služby ve venkovských regionech Česka kvantitatívní hodnocení změn $v$ uplynulém transformačným období (příspěvek ke studiu venkova). In V. Klimová (Ed.), XVI. Mezinárodní kolokvium o regionálních vědách (pp. 212-222). Brno: MU Brno.
Szczyrba, Z., Klapka, P., Kunc, J., \& Tonev, P. (2007). Diffusion Processes in the Czech Retail. Regionální studia, 2007(1), 8-12.

TERNO (2014). Data for retail.

Timothy, D. (2005). Shopping Tourism: Retailing, and Leisure. New York: Channel View Publications.

Trembošová, M. (2010). Vybrané aspekty transformácie maloobchodu $\mathrm{v}$ meste Nitra v rokoch 1992-2008. Geografický časopis, 62(1), 49-73.

Trembošová, M. (2012). Geografické aspekty maloobchodnej siete mesta Nitra. Nitra: UKF.

Urbšienè, L. (2013). The impact of globalisation to transitional economies: Evidence for Lithuania. Transformation in Business \& Economics, 12(1), 140-162.

Wrigley, N. (2000). The globalization of retail capital: themes for economic geography. In G.L. Clark, M.P. Feldman, \& M.S. Gertler (Eds.), The Oxford Handbook of Economic Geography (pp. 292-313). Oxford: Oxford University Press.

Wrigley, N., Coe, N.M., \& Currah, A. (2005). Globalizing retail: conceptualizing the distribution-based transnational corporation (TNC). Progress in human geography, 29(4), 437-457. doi:10.1191/0309132505ph559oa.

doc. RNDr. František Križan, PhD. Comenius University in Bratislava Faculty of Natural Sciences Department of Regional Geography, Planning and Environment krizan@fns.uniba.sk

Mgr. Kristína Bilková Comenius University in Bratislava Faculty of Natural Sciences Department of Regional Geography, Planning and Environment bilkova@fns.uniba.sk

doc. Ing. Pavol Kita, PhD. University of Economics in Bratislava Faculty of Commerce Department of Marketing pavol.kita@euba.sk

Ing. Tomáš Siviček, PhD. Jan Evangelista Purkyně University in Ústí nad Labem Faculty of Social and Economic Studies

Department of Economics tomas.sivicek@ujep.cz 


\title{
Abstract
}

\section{TRANSFORMATION OF RETAILING IN POST-COMMUNIST SLOVAKIA IN THE CONTEXT OF GLOBALIZATION}

\author{
František Križan, Kristína Bilková, Pavol Kita, Tomáš Siviček
}

Retailing is a form of exchange, which mediates the movement of goods between the manufacturer, their transfer and sales to the phase of the field of final consumption. For the past 25 years significant transformation processes have been identified in the retailing of post-communist countries that have both an economic and also spatial character. The aim of this paper is to analyze retailing in Slovakia and its development in the period of 25 years with specific attention paid to the transformation process. In the paper these processes are classified and defined in the time and space context. The conclusions of the study show that in Slovakia some trends in globalization processes can be identified, which are typical in other developed countries. These changes become evident particularly after 1989. The process of atomization of the retail is the first analysed process and it is typical for the transition period from the centrally-planned economy to the market economy. The further processes are related to manifestations of globalization in the Slovakian retail. Those are the processes of internationalization, cooperation, and concentration in the retail. By analyzing all of the changes in the Slovak retail it is then possible to identify several stages of transformation. The characteristics of the globalization processes in the retail sector are more intense in urban areas than in rural. For Slovakia, there is a delayed transition in the processes in comparison with neighbouring countries. The size of the market determines the intensity of the manifestations of the globalization processes. The ultimate consolidation of retailers in Slovakia can be categorized as transformation process in the initial stage of development.

Key Words: Slovakia, retail, spatial economics, geography, policy making, post-communist.

JEL Classification: F60, L81, O18, R11.

DOI: 10.15240/tul/001/2016-1-011 